\title{
The outline of the 2011 eruption at Shinmoe-dake (Kirishima), Japan
}

\author{
Setsuya Nakada ${ }^{1}$, Masashi Nagai ${ }^{2}$, Takayuki Kaneko ${ }^{1}$, Yuki Suzuki ${ }^{1}$, and Fukashi Maeno ${ }^{1}$ \\ ${ }^{1}$ Earthquake Research Institute, the University of Tokyo, 1-1-1 Yayoi, Bunkyo-ku, Tokyo 113-0032, Japan \\ ${ }^{2}$ National Research Institute for Earth Science and Disaster Prevention, Ten' nodai 3-1, Tsukuba, Ibaraki 305-0006, Japan
}

(Received October 30, 2012; Revised March 11, 2013; Accepted March 31, 2013; Online published July 8, 2013)

\begin{abstract}
The climactic phase of the 2011 eruption at Shinmoe-dake was a mixture of subplinian and vulcanian eruptive events, successive lava accumulation (lava dome) within the crater, and repetition of vulcanian events after the dome growth. It was preceded by inflation and elevated seismicity for about one year and by phreatomagmatic explosions of one week before. Small pyroclastic flows and ash-cloud surges formed during the subplinian events, when the eruption column reached the highest level and the vent was widened. A lava dome, which was extruded close to the vent of subplinian events, grew by swelling upward and filling the crater. After the vent was covered by the lava, an intense vulcanian event occurred from the base of the dome and the swelled dome became deflated. After that, vulcanian events were repeated for three months. Simultaneous eruption styles in the crater (vulcanian events, continuous ash emission and dome growth) and some phreatomagmatic events in the vulcanian stage probably are due to a complex upper-conduit system developed in water-saturated country rock.
\end{abstract}

Key words: Subplinian event, vulcanian event, lava dome, phreatomagmatic event, phreatic event.

\section{Introduction}

Plinian or subplinian eruptions sometimes happen after a dormant period as long as hundreds or thousands years. Forecasting them correctly from monitoring data is very critical to save lives of people living on and around the volcanoes. In order to minimize the risks from these eruptions, it is important to understand the precursory phenomena of these explosive eruptions and to illustrate the scenario of the eruption. However, the examples of detailed real-time observations of such eruptions are very few. Some happen suddenly, before monitoring is possible, or where the access to the volcano becomes dangerous. The eruption at Shinmoe-dake volcano, Kirishima, in Kyushu, Japan (Fig. 1), which began in January 2011, is a well-monitored example. This eruption took place about 300 years after the last magmatic eruption. The main phase is represented by subplinian/vulcanian events and successive lava accumulation, which was followed by repeated vulcanian events (Figs. 2 and 3). Subplinian eruptions may be transitional between vulcanian explosions and plinian eruptions in terms of magnitude and intensity (e.g., Cashman, 2004). The transition between two phenomena is common (Cioni et al., 2000; Morrissey and Mastin, 2000; Cashman and McConnell, 2005). Therefore, it is expected that the eruption process of the 2011 eruption at Shinmoe-dake may give the valuable information to illustrate the transition between vulcanian and subplinian eruptions.

This paper outlines the chronology of the Shimmoe-dake eruption, especially the surface manifestations. Individ-

Copyright (C) The Society of Geomagnetism and Earth, Planetary and Space Sciences (SGEPSS); The Seismological Society of Japan; The Volcanological Society of Japan; The Geodetic Society of Japan; The Japanese Society for Planetary Sciences; TERRAPUB.

doi:10.5047/eps.2013.03.016 ual eruption phenomena are called "events" in this paper to avoid confusion with the eruption in 2011 as a whole. "Phreatomagmatic events" are used for long-lasting eruptive events which produced very fine ash having the grain size distribution clearly different from those of subplinian and vulcanian events, but similar to those of phreatic events (figure 13 of Suzuki et al., 2013a), and containing minor amounts of juvenile particles.

\section{Background of Shinmoe-dake}

Shinmoe-dake and Ohachi are the most active eruptive centers in the Kirishima volcano group, Southern Kyushu, Japan (Fig. 1). The volcanic activity of Kirishima started about $600 \mathrm{ka}$ with caldera-forming eruptions, and changed to form stratovolcanoes with plinian, vulcanian, strombolian and phreatomagmatic eruptions about $330 \mathrm{ka}$ (Imura, 1992; Nagaoka and Okuno, 2011). Migration of eruption centers during these 330 thousand years produced more than 25 stratocones and pyroclastic cones. Recent activity at Shinmoe-dake was characterized by phreatic explosions in 1822, 1959 and 1991 (Imura and Kobayashi, 1991; Tsutsui et al., 2005).

According to Imura and Kobayashi (1991), the main phase of the 1716-17 eruption had continued for about three months, including multiple subplinian and vulcanian events. It was preceded by a phreatic event 8 months before, and followed by the large subplinian event about 7 months after. During the subplinian events small-scale pyroclastic flows reached about $2 \mathrm{~km}$ from the crater. The total volume of the tephra is estimated about $0.07 \mathrm{~km}^{3}$ DRE (Imura and Kobayashi, 1991). Before the 2011 eruption, the bottom of the summit crater was covered by a lava flow convex downward with concentric steps on the surface (Figs. 3(A) and 4(A)). Endo and Kobayashi (2012, pp. 165-166) considered that the lava which once had pooled in the crater was 


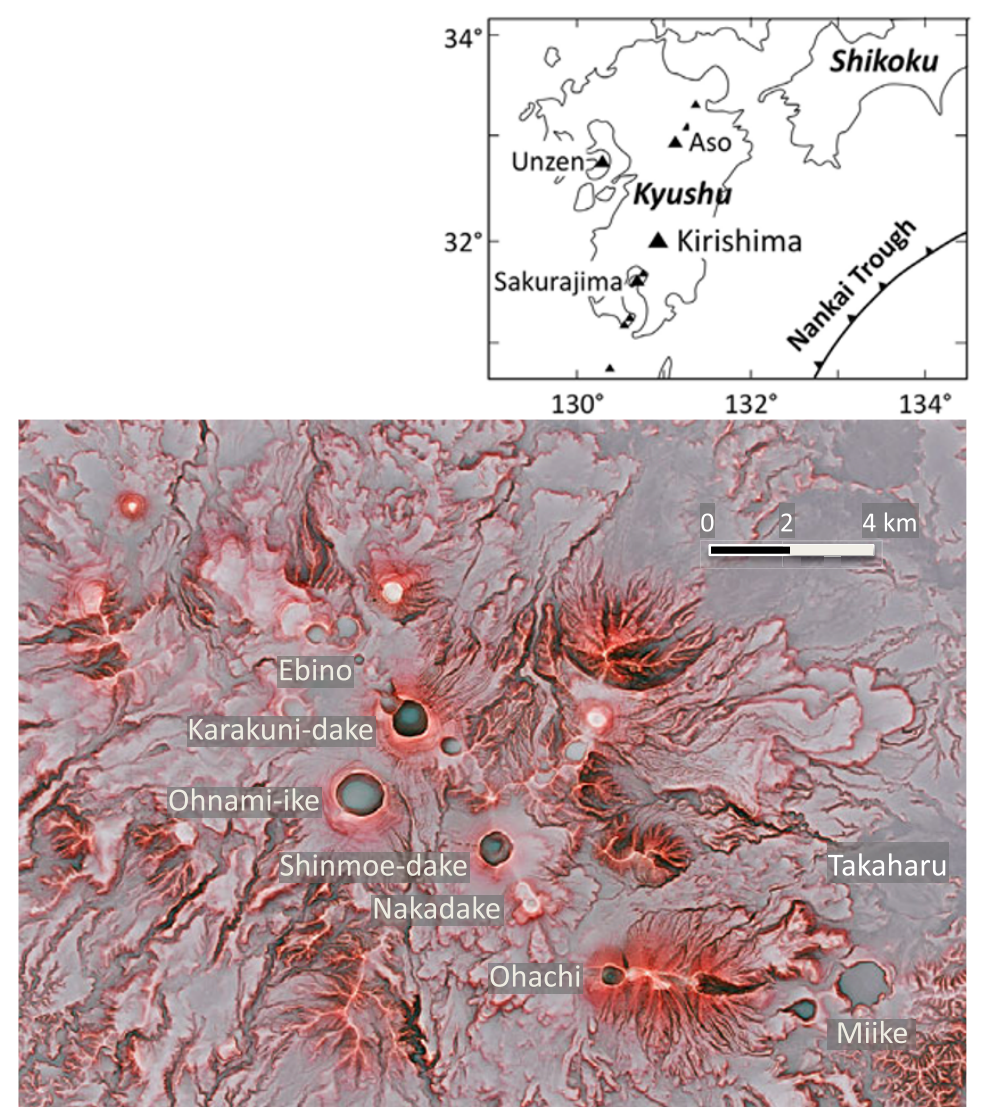

Fig. 1. Location and shaded-relief map of the Kirishima volcano group. The shaded-relief map was produced by the Asia Air Survey Co. Ltd. (JMA, 2005).

drained back into the conduit. Since Tsutsui et al. (2005) concluded that the latest magmatic eruption at Shinmoedake occurred in 1716-1717, the lava at the crater bottom probably is the product of the 1716-17 eruption.

\section{Monitoring and Observation at Shinmoe-dake}

The volcanic activity of Shinmoe-dake has been monitored by Japan Meteorological Agency (JMA), Geospatial Information Authority of Japan (GIAJ), National Institute for Earth Science and Natural Disasters (NIED), national universities and the Kagoshima Prefecture. After the subplinian events at the end of January 2011, the monitoring network was strengthened by each organization. The summit of Shinmoe-dake was monitored with real-time cameras at Onami-ike, about $3 \mathrm{~km}$ west-northwest of Shimoe-dake by the Kagoshima Prefecture and at Inokoishi, about $8 \mathrm{~km}$ south-southwest of Shinmoe-dake by JMA. Those camera records were very helpful to understand the temporal changes in eruption condition, including the height of ash column, the location of eruption site and topography of the summit crater. The Doppler radars in Fukuoka and Tanegashima JMA stations were also used to measure the eruption column height (Shimbori and Fukui, 2012). Satellite SAR images, especially JAXA EROC and terra SAR-X images, were very useful to understand what happened within the crater even in cloudy days and estimate the volume of lava accumulated within the crater (NIED, 2012).

Geological field survey was carried out several times since the afternoon of 27 January 2011. As of the summer 2012, the summit area was restricted to approach even for researchers and observation of deposits near or within the crater area was insufficient. This situation results in large uncertainty of estimation of tephra volume of this eruption. In order to watch the volcanic activity, air inspections were carried our many times with helicopters by JMA, being supported by Self Defense Force, Ministry of Land, Infrastructure and Transport, and Kagoshima Prefecture, and with airplanes hired by researchers.

\section{Chronology of the 2011 Eruption}

\subsection{Phreatic stage and precursory phenomena}

The chronology of the 2011 eruption is summarized in Table 1. The eruption was preceded by phreatic events which occurred on 22 August 2008 (Geshi et al., 2010) and were repeated during March to July 2010. The 2008 event occurred along a fissure in the western outer slope of the crater, the western rim and bottom of the crater (Fig. 4(A)). Vents on the western rim produced successive phreatic events during March-July 2010 (JMA, 2011).

Rapid inflation of the Kirishima volcano group before the main phase of the 2011 eruption was clearly detected in the GPS network by Geospatial Information Authority of Japan (Fig. 5, GIAJ, 2011, 2012). The three baselines of the triangle GPS network anchored at the Ebino (about $15 \mathrm{~km}$ N of Shimoe-dake), Makizono (about $13 \mathrm{~km} \mathrm{WSW)}$ and Miyakonojo (about $10 \mathrm{~km}$ ENE) stations, surrounding 
Table 1. Chronology of the 2011 eruption at Shinmoe-dake.

\begin{tabular}{|c|c|}
\hline \multicolumn{2}{|l|}{ Phreatic Stage } \\
\hline 22 Aug. 2008 & Phreatic event \\
\hline $\begin{array}{l}31 \text { Mar., } 17 \text { Apr., } 6 \text { \& } 27 \text { May, } 27 \\
\& 28 \text { Jun., } 5 \text { \& } 10 \text { Jul. } 2010\end{array}$ & Phreatic events \\
\hline \multicolumn{2}{|l|}{ Subplinian Stage } \\
\hline 19 Jan. 2011 & Phreatomagmatic event \\
\hline 26-27 Jan. 2011 & Continuous activity including three subplinian events \\
\hline 27 Jan. 2011 & Vulcanian even just prior to the third subplinian event \\
\hline \multicolumn{2}{|l|}{ Lava-accumulation Stage } \\
\hline 28-29 Jan. 2011 & Continuous emission of fine ash (phreatomagmatic) \\
\hline 28-31 Jan. 2011 & Continuous lava accumulation event in the crater \\
\hline $28 \& 30$ Jan. 2011 & Vulcanian events during lava accumulation \\
\hline \multicolumn{2}{|l|}{ Vulcanian Stage } \\
\hline $\begin{array}{l}\text { 1, 2, 3, 4, 6, 7, 9, 10,11, 14, 18, } 24 \\
\& 28 \text { Feb., } 1 \text { Mar. } 2011\end{array}$ & Vulcanian events \\
\hline $\begin{array}{l}7 \text { to } 9 \text { Feb., } 28 \text { Feb. to } 1 \text { Mar., } 3 \text { to } \\
4 \text { Mar. } 2011\end{array}$ & Continuous ash emission events (phreatomagmatic) \\
\hline $\begin{array}{l}8,13,23, \& 29 \text { Mar., } 3 \text { \& } 18 \text { Apr. } \\
2011\end{array}$ & Vulcanian events \\
\hline \multicolumn{2}{|l|}{ Phreatomagmatic Stage } \\
\hline $\begin{array}{l}\text { 16, } 23 \& 29 \text { Jun. to } 1 \text { Jul., } 6 \text { Aug., } \\
\text { Aug. } 31 \text { to } 6 \& 7 \text { Sep. } 2011\end{array}$ & Continuous ash emission events (phreatomagmatic) \\
\hline
\end{tabular}

Shinmoe-dake, had elongated by 2 to $4 \mathrm{~cm}$ with nearly constant rate since December 2010. The main source of inflation was determined at about $7 \mathrm{~km}$ northwest of Shimoedake with the depth of 6 to $10 \mathrm{~km}$ (GIAJ, 2012; NIED, 2012; Nakao et al., 2013).

According to the JMA reports (JMA, 2011, 2012), seismic activity at Shinmoe-dake increased first at the time of the phreatic eruption event in August 2008 and second in the phreatic eruptive events during March-July 2010 (Fig. 5). After the phreatic events, the seismic activity declined but remained a higher level up to a few hundred events monthly.

\subsection{Subplinian stage}

Volcanic tremor was first recorded at $01 \mathrm{~h} 27 \mathrm{~m}$ (JST), 19 January and continued from the 19 January afternoon to the morning of 23 January (JMA, 2012). During the volcanic tremor event, the phreatomagmatic eruption occurred and tephra of this event fell on the southeastern area of Shinmoe-dake on the morning of 19 January. The ash contained up to $10 \mathrm{vol} \%$ in volume fresh pumice fragments (Miyabuchi et al., 2013; Suzuki et al., 2013a). The majority of the ash is intensively to partly altered materials as same as the ash of the 2008 and 2010 phreatic events (Suzuki et $a l ., 2013 \mathrm{a})$. Juvenile material in the products of the 19 January 2011 event was very suggestive of approaching of the climactic event. Steaming from these vents had continued until the morning of 26 January. Vigorous steaming was observed at small vents on the crater bottom on 21 January (Figs. 3(A) and 4(A)).

Dark ash clouds began gushing after a small eruptive event at $07 \mathrm{~h} 31 \mathrm{~m}, 26$ January, and the activity increased around $14 \mathrm{~h} 49 \mathrm{~m}$, leading to the first subplinian event (JMA, 2012). A clear increase in seismicity started that morning. Subplinian events occurred three times from the afternoon of 26 January to the evening of 27 January (Fig. 5). The height of the eruption cloud was monitored by the real-time camera of JMA and the Doppler radar (Fig. 6). The maximum column heights were about $7 \mathrm{~km}$ above the crater and almost identical among three events. The column height increased with time and peaked in the latest stages of the first and second events. The third subplinian event occurred about 40 minutes after the first vulcanian event (Fig. 2(C)). The duration of the third subplinian event was shorter than the first two subplinian events and the column was high from the beginning. The photographs of the first event taken from an aircraft by K. Shimousuki (Figs. 2(A) and (B)) show that fountains of gas, ash and blocks collapsed from curling ash-cloud masses on the outer-slope and generated ash-cloud surges. The vent of this eruption was in the southwestern part of the crater (right front in Fig. 2(B)). The site is close to one of the small vents of the phreatic events before the 2011 eruption in the western crater wall (Figs. 4(A) and (B)).

During the subplinian events a small pyroclastic flow descended on the western slope. The deposit was first found from the aircraft in the morning of 28 January 2011 (Fig. 7); trees attacked by this flow were toppled down and burnt. It traveled up to about $1 \mathrm{~km}$ and its toe is about $70 \mathrm{~m}$ wide. The distribution confirmed by the photographs and the Google Earth image (taken on 11 March 2011), traces back to the western part of the crater rim. This suggests that pyroclasts and gas which became the pyroclastic density currents descended not from the lowest part (NW) of the crater rim but over the higher western rim. This pyroclastic flow event occurred at $18 \mathrm{~h} 25 \mathrm{~m}, 26$ January, based on the camera record of JMA; the incandescence was observed in the lowermost western slope of Shinmoe-dake. Simultaneously, the camera record at Ohnami-ike showed the northward migration (or expansion) of the base of eruption column. Ichihara et al. (2013) showed the temporal 

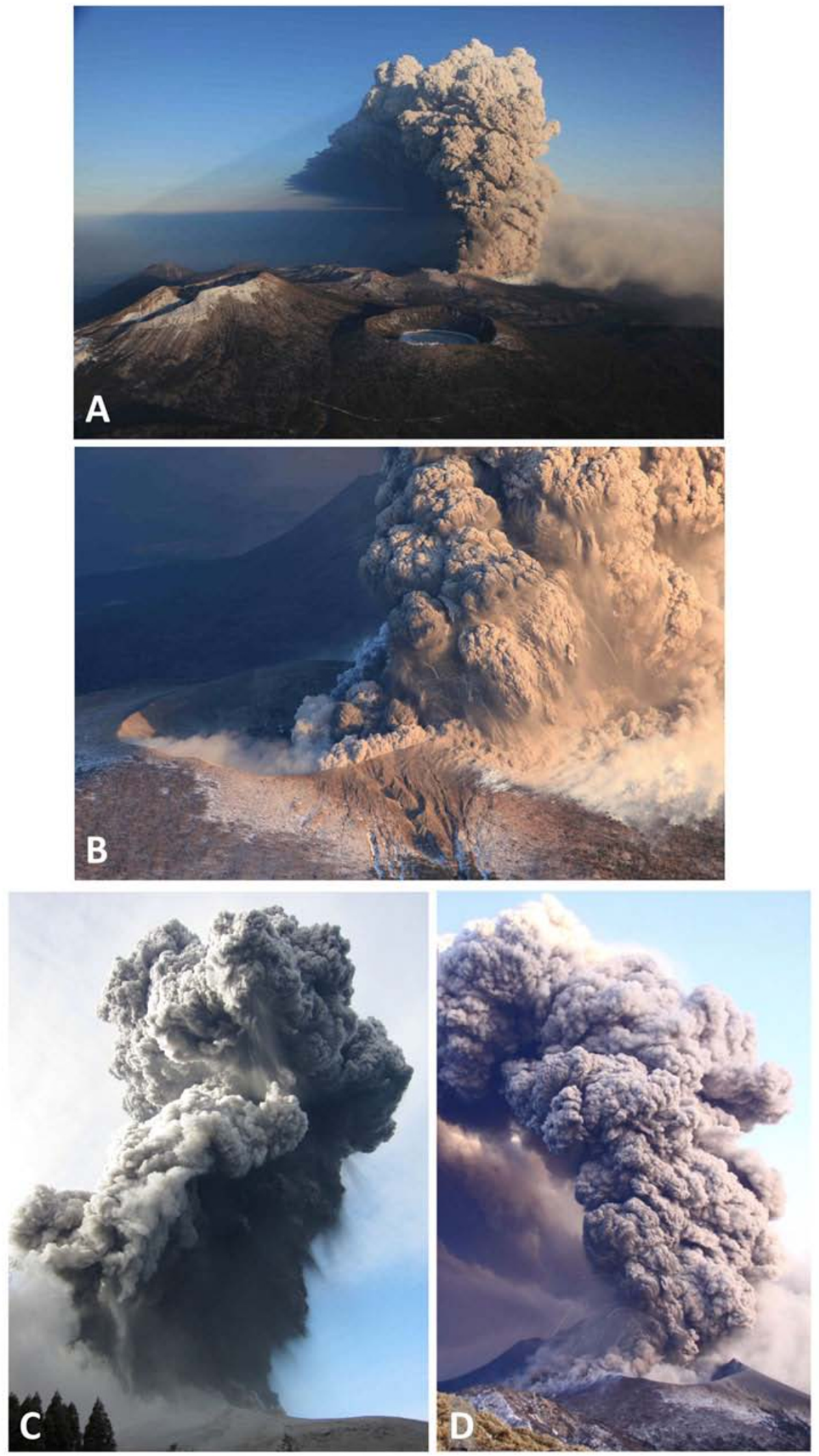

Fig. 2. Photographs showing explosive events at Shinmoe-dake Volcano (Kirishima) on 26 and 27 January 2011. A: Northwesterly view of rising eruption column of subplinian event. Snowcapped volcanic cone in the left, whose northern wall is collapsed, is Karakuni-dake, and the crater filled by water in front is Ohnami-ike. Taken by Kazuo Shimousuki at $17 \mathrm{~h} 14 \mathrm{~m}, 26$ January. B: Westerly view of the summit crater. Grooves on the western outer slope (front) are the vents of the 1959 eruption, aligned east-west and providing a good marker of the direction among the photographs. Explosion occurred southwestern part in the summit crater. Taken by K. Shimousuki at 17h17m, 26 January. C: Eruption column of the first vulcanian event, taken from about $3 \mathrm{~km}$ south of Shinmoe-dake by S. Nakada at $15 \mathrm{~h} 42 \mathrm{~m}$, 27 January. D: Northwesterly view of eruption column of the third subplinian event. Ash overflowed from the summit crater to the northeast. Taken from Karakuni-dake by T. Nagatomo at 17h07m, $27 \mathrm{January}$. 

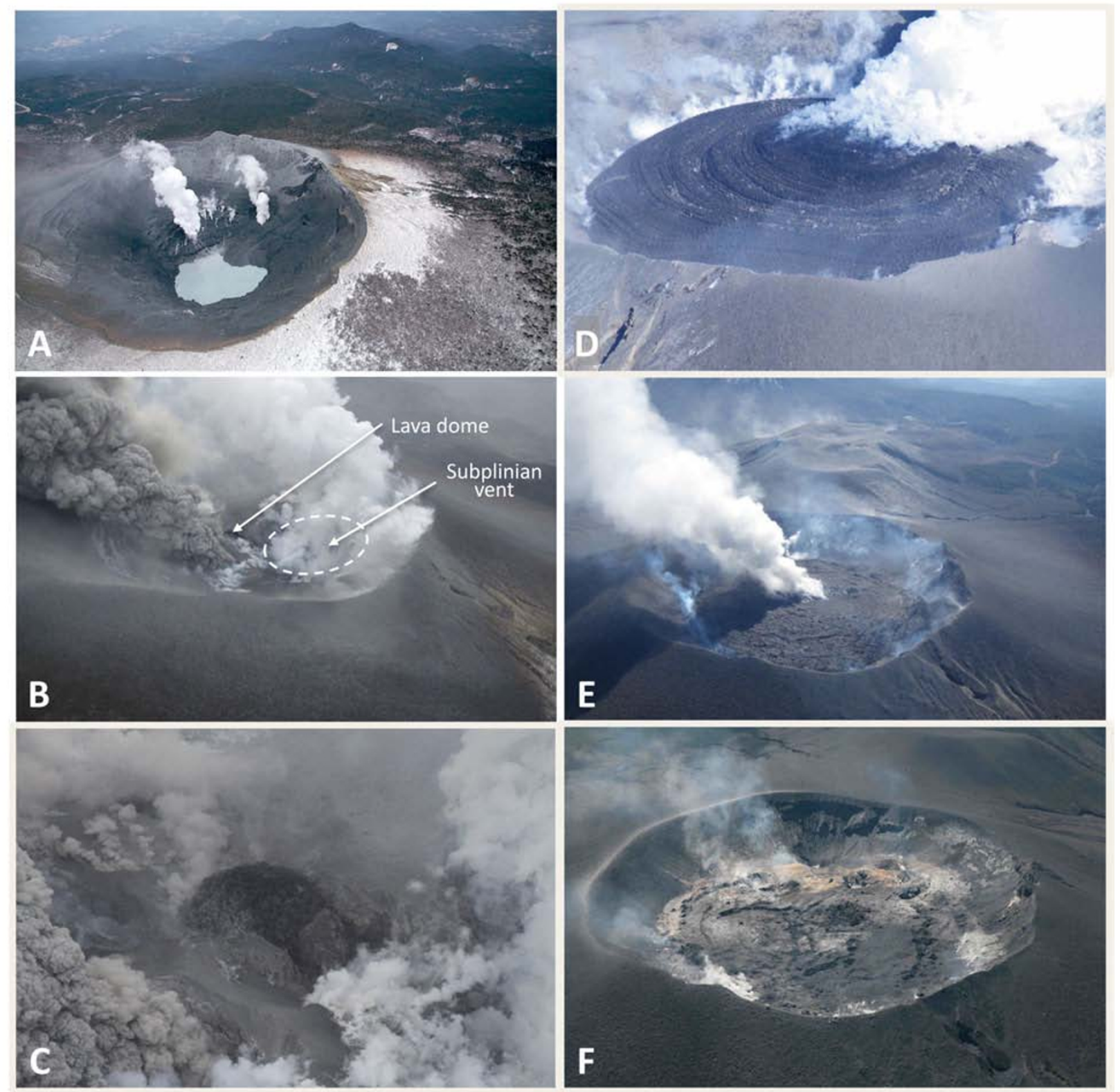

Fig. 3. Photographs showing changes of the summit crater of Shinmoe-dake in 2011. A: Northeasterly view of steaming within the craters after the phreatomagmatic event on 19 January 2011. Dry gray ash of the event covers the southern rim. Irregular small holes on the right side of steaming on the crater wall are vents formed by phreatic events in 2008. Taken by JMA at $14 \mathrm{~h} 23 \mathrm{~m}, 21$ January. B: Northerly view after subplinian events. Continuous emission of fine ash occurred near the open explosion crater of subplinian events, and a small lava dome was found just behind the continuous ash emission. Taken from a light aircraft by S. Nakada at $10 \mathrm{~h} 19 \mathrm{~m}, 28$ January. C: About $50 \mathrm{~m}$ across lava dome was growing, pushing pyroclastic formations aside. Taken from the north by S. Nakada at 10h20m, 28 January. D: Southwesterly view of lava dome which almost filled the summit crater. Taken by T. Kobayashi around $13 \mathrm{~h} 44 \mathrm{~m}, 31$ January. E: Northwesterly view of lava accumulated in the summit crater. Lava ridges were almost covered by vulcanian event products. Taken by S. Nakada on 4 February. F: Northwesterly view of lava in the crater, partly altered by fumarolic activity. Grooves on the surface are the pits formed by repeating vulcanian events. A small vent in the southern margin of the crater (the deepest part in the photo), which is surrounded by reddish yellow ash deposits, appeared in continuous ash emission (phreatomagmatic event) in the end of February or early March. Taken by K. Shimousuki on 13 August 2011.

changes in the amplitude ratio of seismic signals between two seismometers installed south and north of the crater, and proposed northward migration of vents as the ratio decreased in the latest periods of the first and second subplinian events. Rather, these facts seem to indicate the vent was widened in the latest stages of these subplinian events when the eruption columns were highest. In the first event, only a small pyroclastic flow was generated. Widening of vent allowed repeated collapse of the eruption column (Wilson et al., 1980). It is considered that the vent was filled by their own materials after individual subplinian events. During the third subplinian event, pyroclastic surges flowed onto the northeastern slope (Fig. 2(D)). As during the first subplinian event, pyroclastic density currents formed when the eruption column was highest and the base of eruption column expanded to the north (Fig. 6).

\subsection{Lava accumulation stage}

Following the subplinian events, a lava dome appeared within the crater. This finally filled the lower half of the crater (Fig. 4(C)). The lava dome was first found from an 


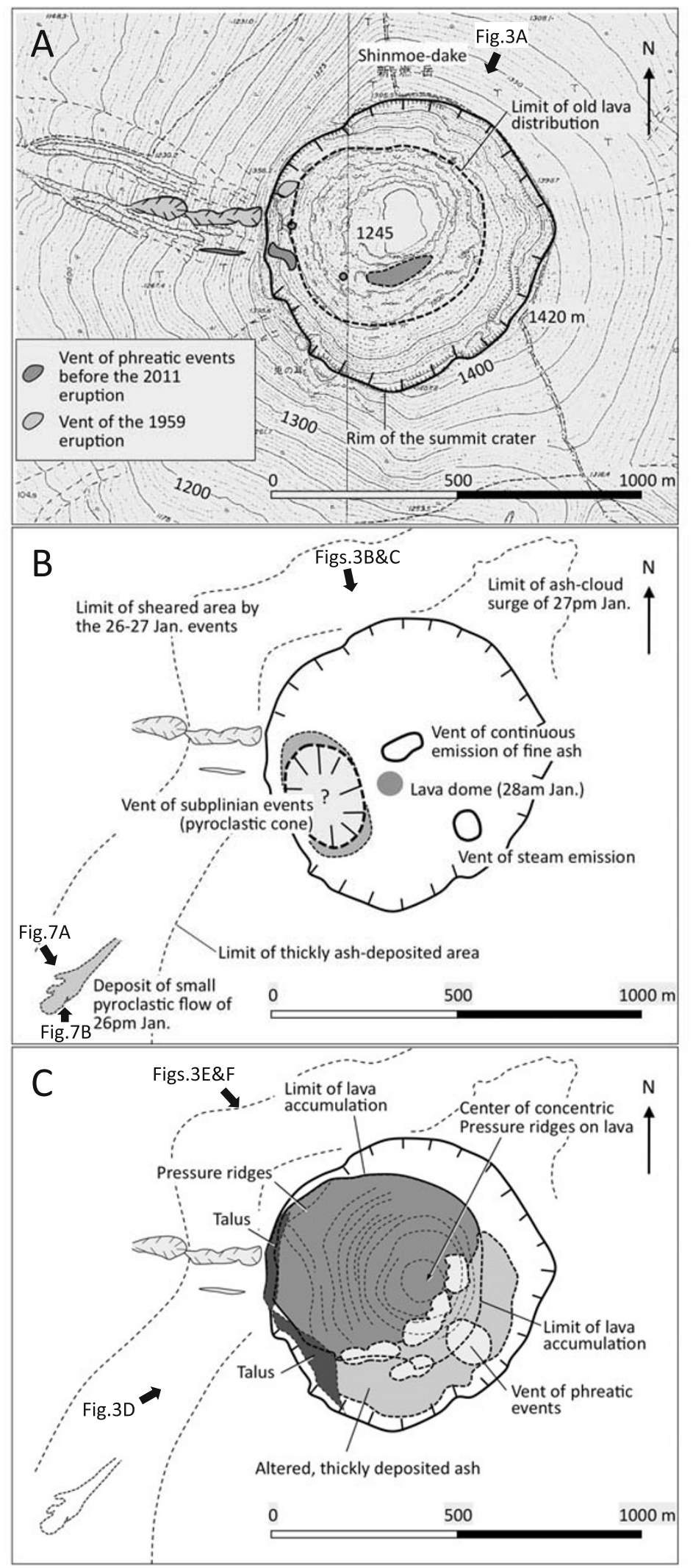

Fig. 4. Maps showing the temporal change of the summit crater of Shinmoe-dake and the surrounding area. A: Before the 2011 eruption. The southern vents in the summit crater were used in the January 19 event. Distribution of vents including fissure vents of phreatic eruption in 1959 are after Geshi et al. (2010). B: On the morning of 28 January 2011. Within the crater, the open explosion vent (west side), the growing lava dome and the vent (east side) from which volcanic ash was continuously emitting. C: In the summer of 2012. The center of concentric pressure-ridges is emission point of lava, which locates near the center of the crater before the 2011 eruption. The surface of the lava dome, which grew during 28-31 January 2011 , was broken by successive vulcanian events after 1 February 2011 and thickly covered by blocks and ash derived from the dome. 


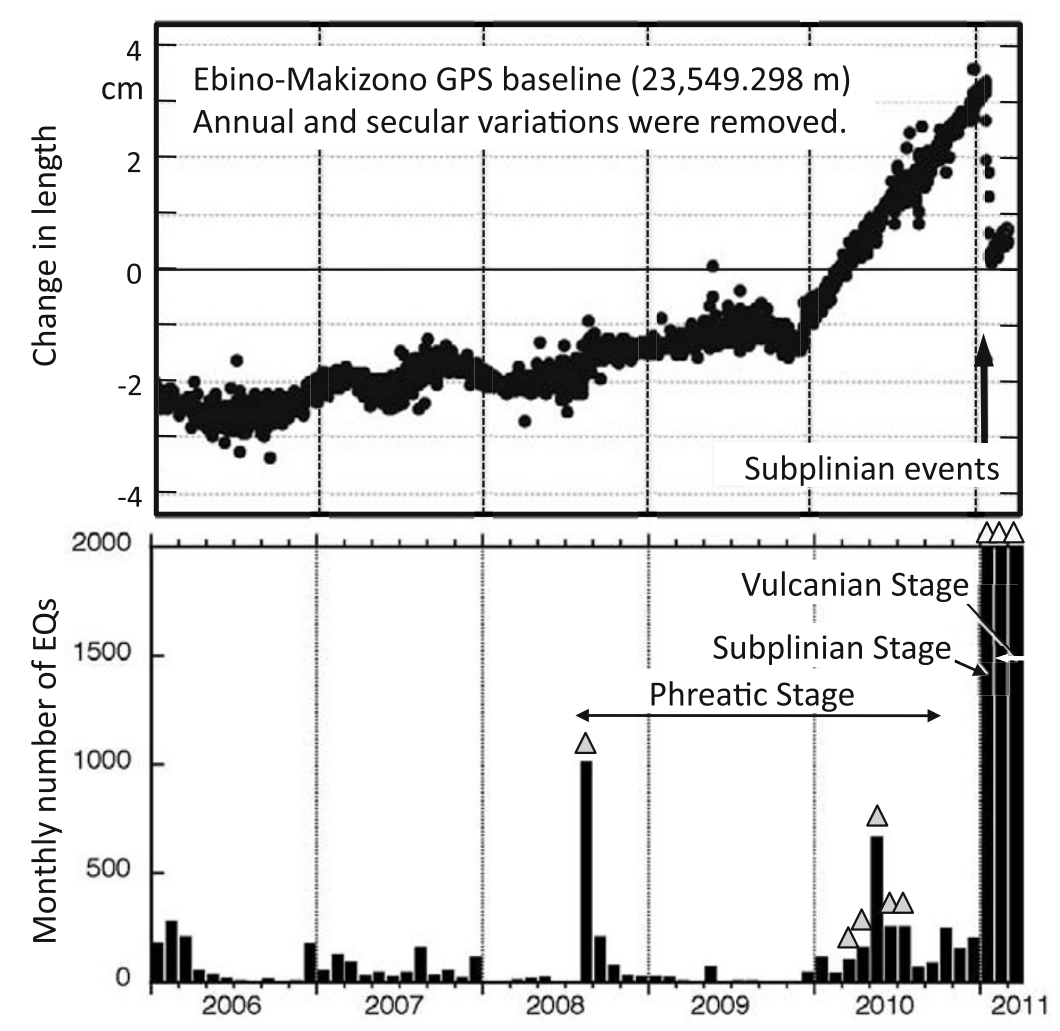

Fig. 5. Temporal variations in the GPS baseline length (Ebino-Makizono) and the monthly number of earthquakes around Shinmoe-dake. The Ebino GPS site is about $16 \mathrm{~km} \mathrm{~N}$ of Shinmoe-dake, and the Makizono site is about $14 \mathrm{~km} \mathrm{SW}$ of Shinmoe-dake. The upper diagram is from the data of Geospatial Information Authority of Japan (GIAJ, 2012). In the lower diagram, the months when eruptive event(s) occurred are shown by triangles; gray and white triangles are for phreatic and magmatic events, respectively. Numbers of earthquakes are from JMA.

aircraft on 28 January 2012 (Figs. 3(B), 3(C) and 4(B)), about $50 \mathrm{~m}$ across and located near the pyroclastic cone formed around the vent of the subplinian events. The incandescence of the dome was observed in the sun-shaded angle. The surface of the dome was black and irregular in morphology like a gigantic cauliflower (Fig. 3(C)). Beds of pyroclastic materials, a few meters thick around the base of the dome, had been torn and lifted by intruding lava.

The lava grew, forming concentric pressure-ridges and keeping the dome shape (Fig. 3(D)), and covered the most area of the crater floor by 31 January (Fig. 4(C)). Vigorous steaming from the top of the dome was visible in daytime and incandescence after dark. The top of the lava dome could be seen over the crater rim by the real-time camera at Ohnami-ike. The camera was set at the $1366 \mathrm{~m}$ in altitude, almost same altitude as the western crater rim of Shinmoe-dake. The dome height was roughly estimated as $1380 \mathrm{~m}$ in altitude on the noon of 31 January. However, the dome top became invisible from the camera after the vulcanian event on the morning of 1 February. The height on 1 February was about $1350 \mathrm{~m}$ according to the SAR analysis (GIAJ, 2012). This means that the dome-shaped lava became deflated after the 1 February vulcanian event, losing about $30 \mathrm{~m}$ in height. The vent for final lava accumulation in the crater is represented by the center of concentric ridges (Fig. 4(C)). Widths of ridges are not homogenous. In the western marginal part of the lava, the ridges are widest, implying faster motion of the lava there in the early stage of dome growth. Since the western part was the vent of the subplinian events (Fig. 4(B)), it is likely that lava flowed into and filled the vent.

Continuous and vigorous emission of fine ash, which was drifted to the east, was observed on the morning of 28 January (Figs. 3(B), and (C); phreatomagmatic event in Table 1). The ash contained juvenile scoria and pumice up to $20 \%$ (Suzuki et al., 2013a). The ash emission vent was located in the center of the crater adjacent to the growing lava dome, where a pond occupied before the eruption (Figs. 4(A) and (B)). This emission continued until the night of 29 January, probably when the vent was covered by growing lava.

Volcanic tremor event started on the morning of 26 January and ended on the afternoon of 7 February (JMA, 2012). The extensometer observation clearly recorded the strain change resulting from magma discharging in this eruption (Ishihara and Teraishi, 2011) and slow strain even after 31 January until 10 February 2011. These facts suggest that the magma leaking continued at a low rate into early February. The inflation of the volcano stopped abruptly with the subplinian event on 26 January. About 2/3 of the inflation was canceled by the deflation during 26-31 January. The deflation source was similar to that of the inflation source (GIAJ, 2012; NIED, 2012; Nakao et al., 2013). Soon after the effusion of lava (February 2011), the elongation of the three baselines resumed, suggestive of re-inflation of the magma chamber. The rate of the latter inflation was similar to that from December 2010 to just before the subplinian events, it then slowed and stopped in early 2012. 


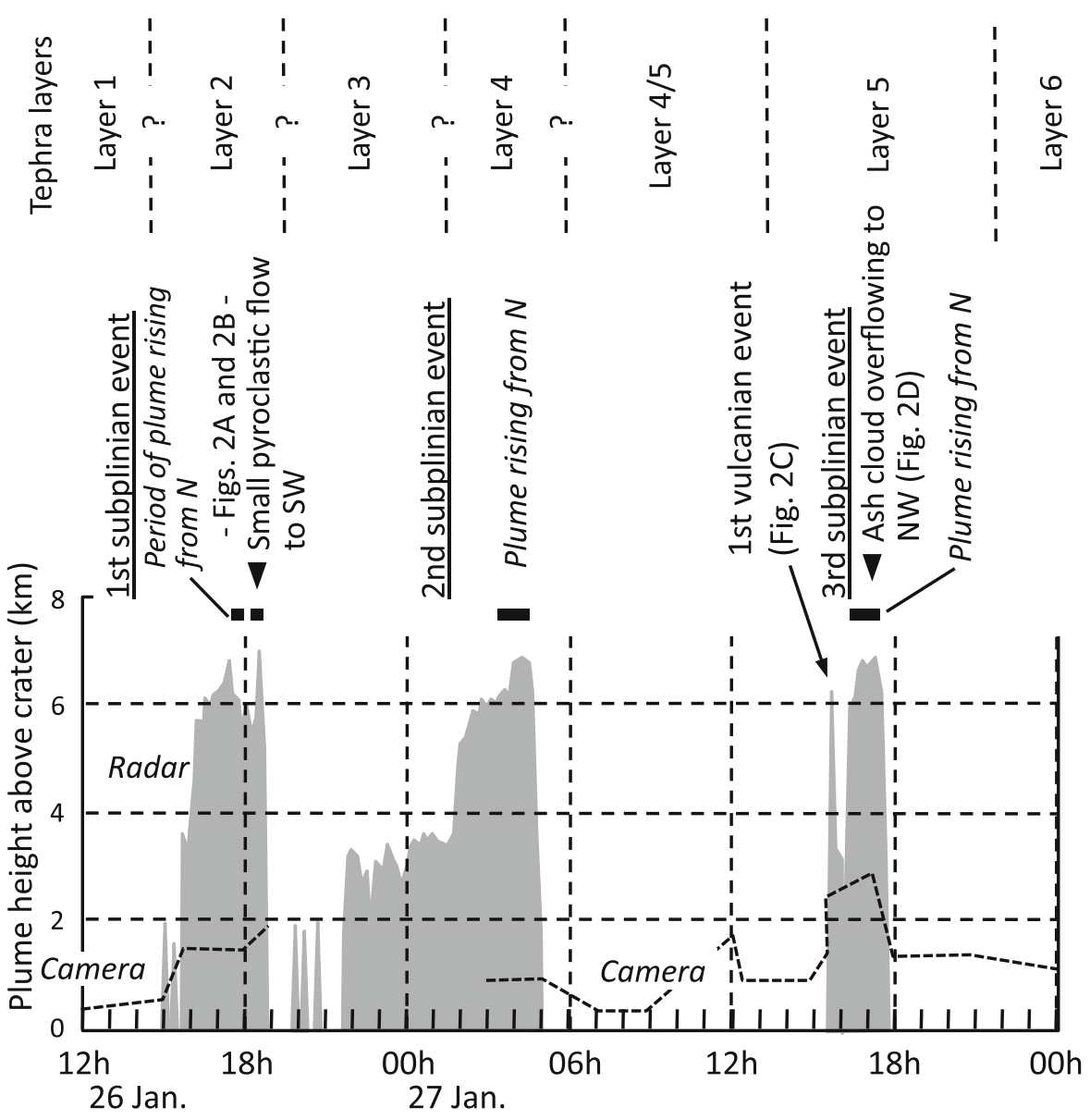

Fig. 6. Time sequence of subplinian events and height of the eruption column. The height changes estimated with Doppler radars and camera (Shimbori and Fukui, 2012) are shown in gray color and dashed line, respectively. The latter provides the minimum height. Layers of deposits corresponding to individual eruptive events are shown in the top.

\subsection{Vulcanian stage}

Vulcanian events occurred first at $15 \mathrm{~h} 41 \mathrm{~m}$ of 27 January, at $12 \mathrm{~h} 47 \mathrm{~m}$ of 28 January and $13 \mathrm{~h} 57 \mathrm{~m}$ of 30 January (JMA, 2012). By the first vulcanian event, hot pumice fragments, up to $15 \mathrm{~cm}$ across, and smaller lithic fragments fell about $2.9 \mathrm{~km}$ southeast of the crater (Fig. 3(C)). The latter two events occurred in the vent of the subplinian events during the lava dome growth in the crater. As they produced much smaller intensity shock waves than the event of 1 February (JMA, 2012), we infer that the vent had not yet been covered completely by the lava by the noon of 30 January. The event at $07 \mathrm{~h} 54 \mathrm{~m}$ of 1 February 2011 was so violent that ballistic blocks with the weight of 1-2 t reached about $3.4 \mathrm{~km}$ west of the crater (Maeno et al., 2013). The camera record showed that the eruption cloud of this event projected westward and eastward. The aerial inspection on 4 February confirmed that the western and eastern walls of the crater were covered thickly by black colored deposits of fresh lava blocks and fragments (Fig. 4(D)). These facts suggest that the explosion occurred from the base of the lava, like a sudden escape of gas from margins of cooking pan cover. Sealing the subplinian vent by lava prohibited degassing from magma and resulted in the vulcanian event that day.

The black pressure-ridged surface of the lava was completely covered with eruption products of repeated vulcanian events, like a sand pool (Figs. 3(E-F)). The vulcanian events created many small pits aligned concentrically, likely along the pressure-ridges (Fig. 3(F)). As mentioned above, the magma discharge had declined since 1 February and almost stopped after 10 February. Therefore, the pressurization needed for the vulcanian outbursts may have been mainly due to crystallization of the lava accumulated within the crater. However, the ash of the vulcanian events during February to April 2011 contains particles of pumice and scoria as much as $15 \%$, which were depleted in microlites (Suzuki et al., 2013a). This may suggest that continuous degassing in the upper part of the conduit also contributed to the pressurization.

Vulcanian events occurred in March-April 2011, decreasing in frequency with time. The event with the highest eruption column (6 km above the crater; JMA, 2012) was observed on 13 March 2011. Some events in this stage were prolonged and emitted fine ash for more than several hours (Table 1). The SAR images showed that the open vent in the southern part of the crater, which was steaming vigorously during the aerial inspections in February 2011 (Fig. 4(B)), enlarged between the end of February and the beginning of March 2011 (NIED, 2012). Repeated eruptive events may have widened this southern vent. The vulcanian stage was followed two months later by phreatomagmatic events in June 2011 and from August to September 2011.

Tephra of phreatomagmatic events in June to September 


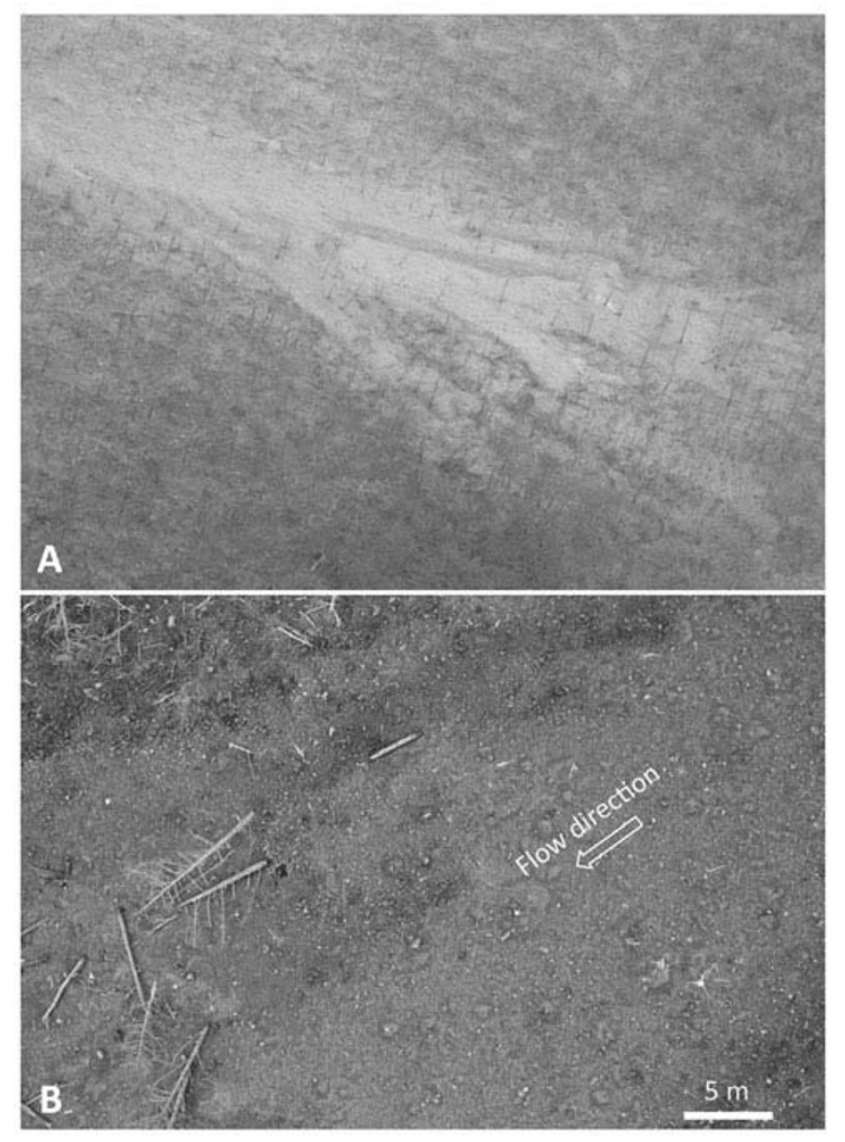

Fig. 7. Pyroclastic flow deposits on the southwestern slope of Shinmoe-dake. A: Northerly view of the pyroclastic flow deposits. Trees in the deposits were smoking on the morning of 28 January 2011. B: Close-up view of the toe of the pyroclastic flow deposits (A), taken from the unmanned autonomous helicopter on 27 May 2011 (Kaneko et al., 2011).

consists of particles finer than those of vulcanian events (Suzuki et al., 2013a). Fine particles of fresh lava occur together with recycled vulcanian products, which are lusterless, partly altered and oxidized. The dispersion and fragmentation index falls near the Surtseyan-field in the Walker diagram (Miyabuchi et al., 2013). After 10 September 2011, no further eruptive activity occurred.

\section{Crisis Management}

JMA raised the volcanic alert level (Kato and Yamasato, 2013) from 2 to 3 at 18 h of 26 January 2011 and access was restricted within $2 \mathrm{~km}$ from the crater center. After due consultation with local municipalities, the limit area was expanded under the same alert level from 2 to $3 \mathrm{~km}$ on 31 January when the lava dome filled the crater, and from 3 to $4 \mathrm{~km}$ on 1 February when ballistic blocks fell $3.2 \mathrm{~km}$ from the crater center. The SAR images taken at $22 \mathrm{~h} 36 \mathrm{~m}$, 29 January, and 10h39m, 30 January (GIAJ, 2012), showed continuous growth of the lava dome in the crater. This information was forwarded to the Takaharu Town, Miyazaki Prefecture, through JMA. The Takaharu Town is just $2 \mathrm{~km}$ east of Shiinmoe-dake (Fig. 1) and within the pyroclasticflow hazard area of the hazard map, which was published by the local governments in 2009 and distributed to local people.
Based on the information of dome growth, the town officials decided by themselves to recommend evacuation of about 1100 people living in the area close to the volcano at the night of 30 January, because of the danger of pyroclastic flow. However, the dome growth rate was very high and there was a high risk of intense vulcanian event due to insufficient degassing. The evacuation recommendation was canceled on 5 February, except for the area closest to Shinmoe-dake. The limit area was reduced to $2 \mathrm{~km}$ from the crater center by June 2012.

\section{Eruption Products \\ 6.1 Tephra}

Tephra of this eruption was widely distributed to the southeast of Shinmoe-dake (Fig. 8; Maeno et al., in review). Although the exact thickness near the crater is unknown when this paper is written, rough estimation was possible by abundant photographs taken from the air and by a quick survey on the southern rim in the 2012 summer as illustrated in Fig. 9. Maeno et al. (in review) estimated the eruption column heights for these events as $7.6-9.8 \mathrm{~km}$ in altitude (6.2-8.4 km above the crater), based on the distribution of tephra and maximum pumice fragments. The numbers are close to the Doppler radar measurement (Fig. 6).

Deposits of three subplinian events, continuous ash emission, and in the vulcanian stage can be easily distinguished in outcrops (Fig. 9). Layer 1 is a light yellow, thin layer covering the soil, and formed mainly from phreatomagmatic events of January 19 and the morning of January 26. Layer 2 consists mainly of pumice lapilli and lithic ash which become coarser upward, and is from the early part of subplinian event from 14h, 26 January. Layer 3 consists mainly of coarsest pumice fragments. Many leaves and stems of trees are observed near the boundary between the layers of 2 and 3, implying that leaves and shrubs fell due to falling of coarse pumice fragments. Layer 4 is of pumice lapilli smaller than in Layer 3, showing upward coarsening. Near the crater, a layer of lithic-rich dark gray ash is the boundary between layers 3 and 4 (layer 3/4 in Fig. 9(C)), and was deposited during a calm period between two subplinian events. Near the crater (Fig. 9(C)), an agglutinate layer thicker than a few tens of $\mathrm{cm}$ correlates with the uppermost part of layer 3, and the uppermost part of layer 4 is also found as agglutinate as thick as $30 \mathrm{~cm}$.

Correlation of layers 2, 3 and 4 with the eruptive events is still uncertain (Fig. 6). Layer 4 is overlain by layer $4 / 5$, a thin black layer of lithic-rich ash that was confirmed in the afternoon of 27 January, $2.9 \mathrm{~km} \mathrm{~S}$ of Shinmoe-dake. Layer 5 is the deposit, lighter in color, from the vulcanian event at $15 \mathrm{~h} 41 \mathrm{~m}, 27$ January and the end of the third subplinian event. This also shows upward coarsening. The topmost part of the layer 5 contains large pumice fragments with tree stems and leaves. Layer 6 is a thin layer of purple to dark gray fine ash during 28-29 January. Layer 7 consists of medium to coarse lapilli of glassy lava, gray to light brownish gray, which is the product of vulcanian events repeated from 1 February. The majority of the layer 7 is the product of the 13 May event.

Layer 6 inhibited infiltration of rainwater, so that the area covered by this layer had the risk of lahar when heavy rain 

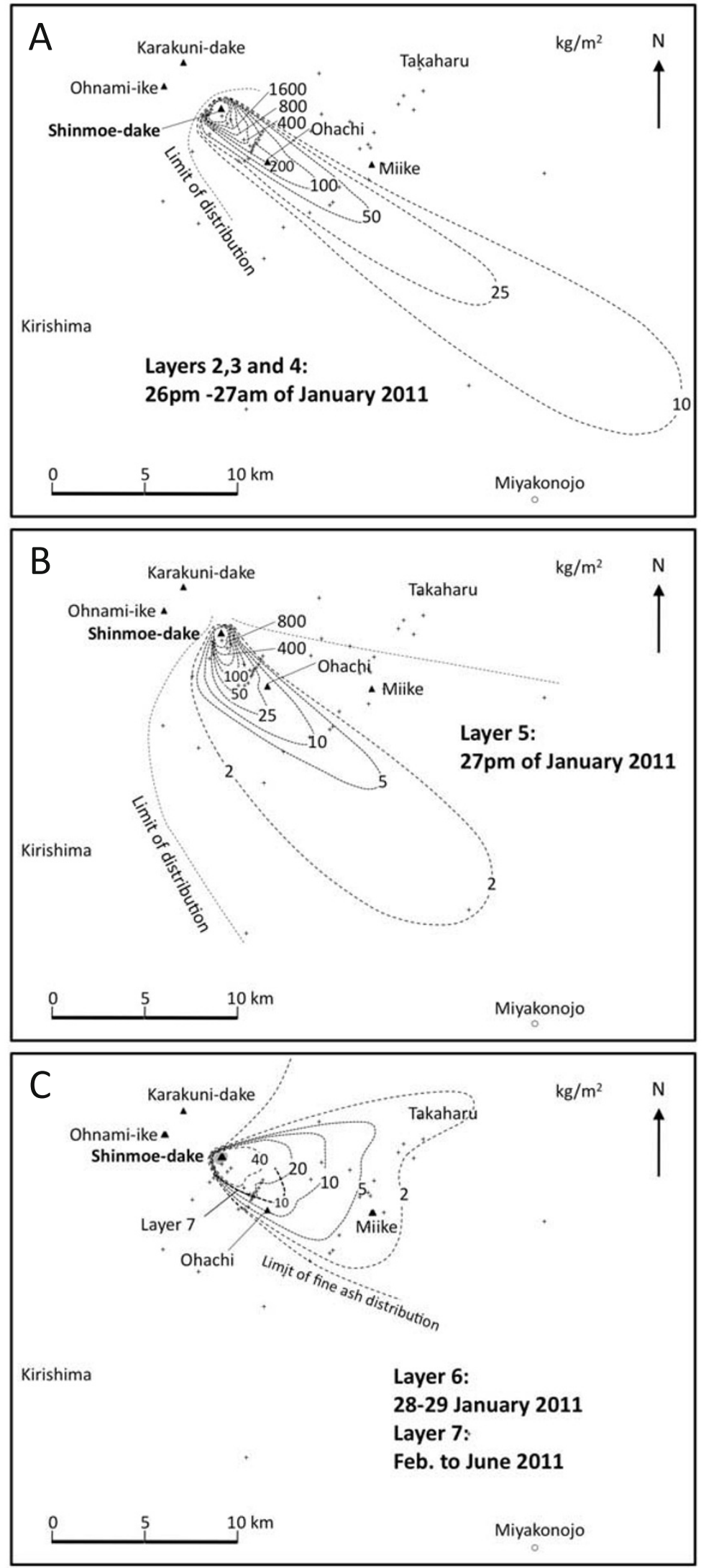

Fig. 8. Isomass maps of tephra from the eruptive events around Shinmoe-dake in 2011 (modified from Maeno et al., in review). Small crosses are the inspection sites. 


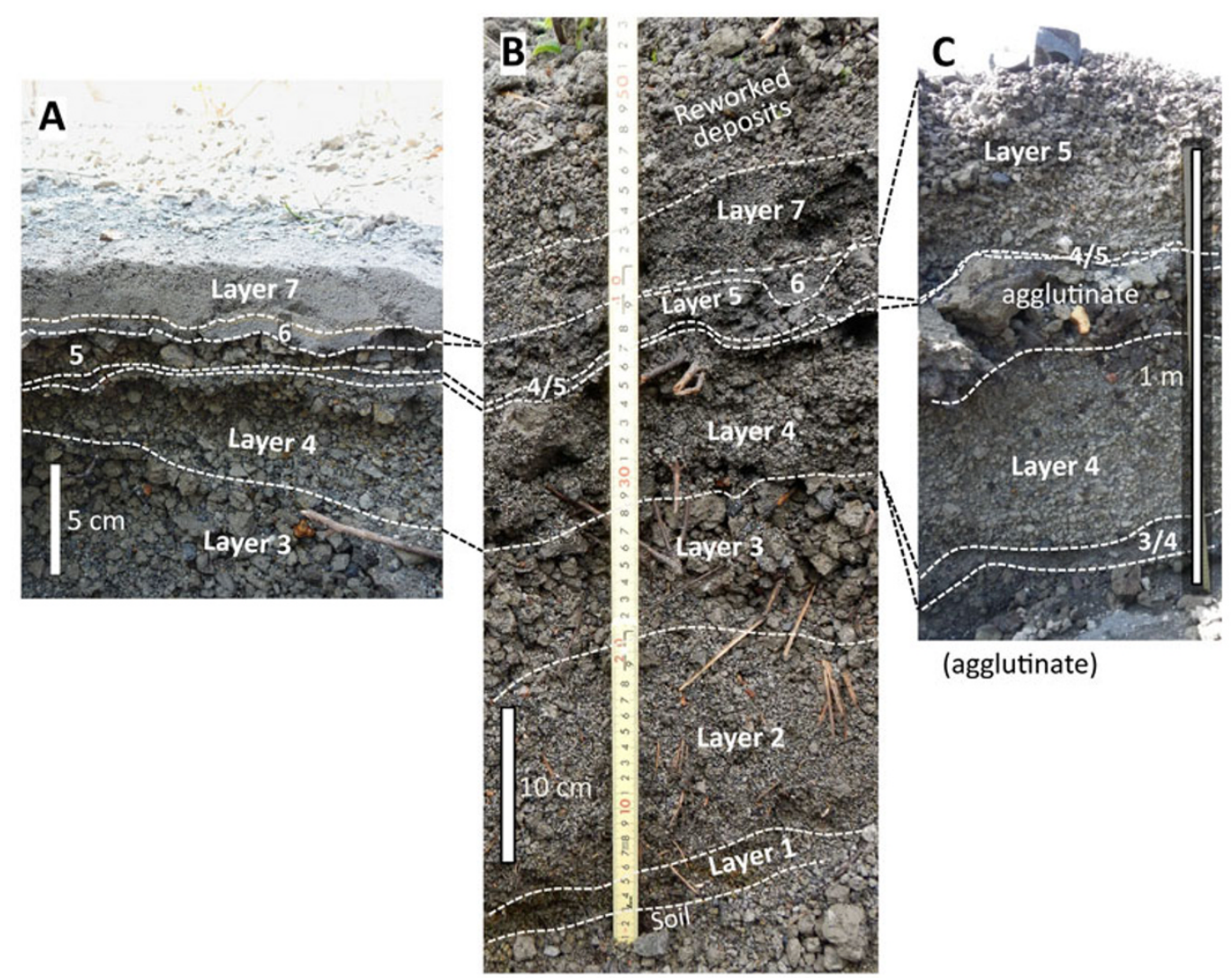

Fig. 9. Representative outcrops of tephra of the 2011 eruption. A: about $3 \mathrm{~km} \mathrm{SE}$ of the Shinmoe-dake. B: about $2 \mathrm{~km} \mathrm{~S}$ of Shinmoe-dake, on the southern slope of Nakadake. C: about $500 \mathrm{~m}$ from the crater rim, on the southern slope of Shinmoe-dake.

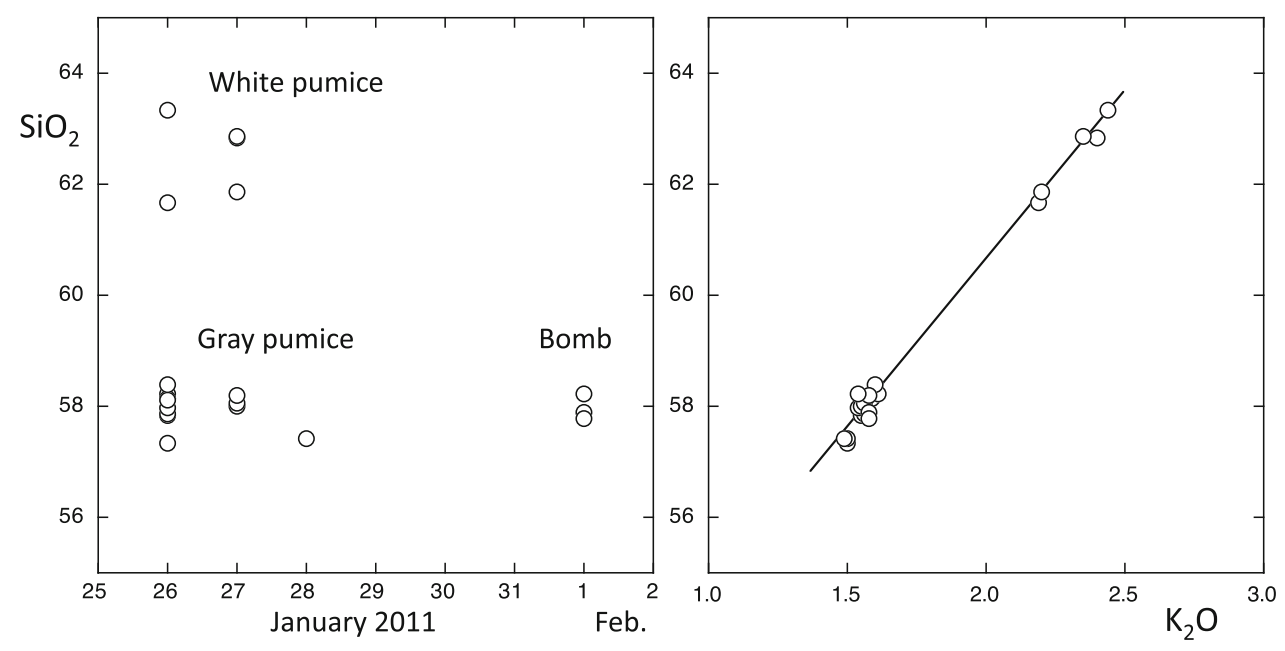

Fig. 10. The whole-rock chemical composition of pumice and lava fragments of the 2011 eruption at Shinmoe-dake. Pumice lumps with different SiO 2 contents were erupted in the subplinian events. The data are after Suzuki et al. (2013b).

fell. Fortunately no large lahar formed during the eruption (Shimizu et al., 2011).

\subsection{Chemistry}

The erupted magma ranges from andesite to silicic andesite in chemical composition (Fig. 9). White-colored, and gray-colored pumices were issued simultaneously during the subplinian events. Mingling of both magmas in a single pumice lump is also found. The lava that accumulated in the crater is andesite with the composition of gray pumice. Therefore, mixing of magma with different compositions is suggested by Suzuki et al. (2013b) and Miyabuchi et al. (2013). The pumice and lava are plagioclase-phyric with lesser olivine, orthopyroxene, clinopyroxene and Fe-Ti oxides. Suzuki et al. (2013b) estimated that the endmembers of mixing were phyric silicic andesite magma at $870^{\circ} \mathrm{C}$ and aphyric basaltic andesite magma at $1030^{\circ} \mathrm{C}$. They also proposed storage depths of these magmas before mixing at 5 and $10 \mathrm{~km}$, respectively. 


\section{Volume of Erupted Magma}

The lava dome started growing on the morning of $28 \mathrm{Jan}-$ uary and almost stopped by 31 January though it continued to grow slowly for another week as written above. The volume of lava accumulated at the crater was estimated as 14$18 \times 10^{6} \mathrm{~m}^{3}$ by using the oblique photographs and the SAR images taken on 31 January and 1 February, respectively (Sasaki et al., 2011; GIAJ, 2012; Kozono et al., 2013). The magma discharge rate was about 41-52 $\mathrm{m}^{3} / \mathrm{s}\left(1.0-1.3 \times 10^{5}\right.$ $\mathrm{kg} / \mathrm{s}$ ), assuming the density of $2,500 \mathrm{~kg} / \mathrm{m}^{3}$.

The mass of tephra erupted during the afternoon of 26 January and the early morning of 27 January is about 1.4$2.5 \times 10^{7} \mathrm{t}$ (Maeno et al., 2013); that of tephra in the afternoon of 27 January, including the products of the first vulcanian and third subplinian events, is about 2.4-4.8 $\times 10^{6} \mathrm{t}$. Fine ash continuously emitted in 28 and 29 January is about $1.2 \times 10^{6} \mathrm{t}$. The total mass of the tephra erupted during 2629 January is $1.8-3.1 \times 10^{7} \mathrm{t}\left(0.7-1.2 \times 10^{7} \mathrm{~m}^{3}\right.$ in DRE). This estimated volume is a little smaller than the volume of magma calculated with the tilt changes by Kozono et al. (2013); $1.6 \times 10^{7} \mathrm{~m}^{3}$ DRE. They estimated the magma volume for tephra by partitioning tilt changes between subplinian events and lava accumulation into the volumes of tephra and the lava $\left(1.5 \times 10^{7} \mathrm{~m}^{3}\right)$. The volume of lava by SAR analysis (Kozono et al., 2013) includes new tephra beneath the lava. The thickness of tephra under the lava is considered to be a few tens of $\mathrm{m}$. The additional difference may come from assumption of identical compressibility of magma at the source between the subplinian events and lava accumulation.

The total amount of magma erupted in the 2011 eruption is $2.1-2.7 \times 10^{7} \mathrm{~m}^{3}$ DRE (tephra of $0.7-1.2 \times 10^{7} \mathrm{~m}^{3}+$ lava of $1.5 \times 10^{7} \mathrm{~m}^{3}$ ). This is a low-end VEI 3 eruption.

\section{Discussion}

\subsection{Comparison with the 1716-17 eruption}

The tephra volume of the 1716-17 eruption is calculated as about $7 \times 10^{7} \mathrm{~m}^{3}$ DRE based on Imura and Kobayashi (1991) and is about 7 times larger than that of the 2011 eruption $\left(0.7-1.2 \times 10^{7} \mathrm{~m}^{3}\right)$. The $1716-17$ eruption was more explosive than the 2011 eruption, and at least 5 subplinian events occurred being associated with pyroclastic flows of the scale larger than in 2011. The sequence of the 2011 eruption was simpler than that of the 1716-17 eruption.

Before 2011, the crater floor was covered by lava which seems to be the remnant of the lava drained back into the conduit (Endo and Kobayashi, 2012, pp. 165-166). This lava is considered to be the final product of the 1716-17 eruption. Similar lava drain-back may have occurred even in the 2011 eruption. However, the lava remained at least when the paper was written (March 2013). The lava viscosity may have become too high due to cooling to drain back into the conduit.

\subsection{Transition from subplinian, vulcanian and dome growth}

The first vulcanian event occurred after the second subplinian event. Repetition of subplinian and vulcanian are reported in several volcanoes; for example, the 1980 summer eruption at Mount St. Helens (Cashman and McConnell, 2005), and the transition is common in the waning stage
(Morrissey and Mastin, 2000). Probably accumulation magma pressure for about 8 hours after the second subplinian event caused fragmentation of solidified magma in the upper part of the conduit, which had behaved as a cap rock for the underlying molten magma. The products of the first vulcanian event contain particles of pumice and fresh lava fragment (Suzuki et al., 2013a). Some of large pumice fragments of this event are polygonal and variable in vesicularity, probably implying that the magma was partly quenched under the ground and fragmented by the vulcanian event.

The magma discharge rates were $0.6-1.4 \times 10^{6} \mathrm{~kg} / \mathrm{s}(240$ $560 \mathrm{~m}^{3} / \mathrm{s}$ ) for the first and second subplinian events and 0.2 $1.1 \times 10^{6} \mathrm{~kg} / \mathrm{s}\left(80-440 \mathrm{~m}^{3} / \mathrm{s}\right)$ for the first vulcanian and the third subplinian event (Maeno et al., in review). The rate for lava accumulation was one order of magnitude lower $\left(1.0-1.3 \times 10^{5} \mathrm{~kg} / \mathrm{s}\right.$ or $\left.41-52 \mathrm{~m}^{3} / \mathrm{s}\right)$, but as high as the rate that elsewhere has led to subplinian and vulcanian eruptions (Cashman, 2004). The reason that rapid dome growth continued without transition to more explosive eruption is probably that degassing from the underlying magma was effective through the vents of the subplinian events and fine-ash emission events. However, the second and third vulcanian events which occurred during the dome growth may have reflected insufficient degassing.

\subsection{Interaction with water}

Emission of fine ash on 28-29 January was a phreatomagmatic event. Fresh glassy particles dominate the ash, and the dispersion-fragmentation index of this tephra falls in the Surtseyan field of the Walker's (1973) diagram (Miyabuchi et al., 2013). In addition, vigorous steaming in the southern part of the crater had continued since 28 January (Figs. 3 and 4). These facts suggest involvement of groundwater during the 2011 eruption. The magnetotelluric experiment showed a low resistivity layer is extensively distributed at the depth of a few hundred meters under Shinmoe-dake, which can be interpreted as a water-saturated porous layer (Kagiyama et al., 1996). Under such the circumstance, the ascending magma likely interacts with groundwater. Coexistence of multiple vents within the crater for subplinian and vulcanian events during 26-30 January, the lava dome, continuous ash emission and vigorous steaming (Fig. 4(B)) imply a complex system in the upper part of the conduit. The reason that the magma which formed the lava dome did not ascend into the subplinian vent may be that it could ascend only where groundwater was not present.

\section{Conclusions}

Precursory phenomena of the 2011 eruption at Shinmoedake were inflation and seismicity since the end of 2009 and repeated phreatic eruption since 2008. Juvenile material in the ash of 19 January foreshadowed the fully magmatic stage which began on 26 January.

The first two subplinian events were relatively long but included periods with a low eruption column, and each event ended with the highest eruption column. Duration of the third subplinian event was short and preceded by the first vulcanian event. When the eruption column was highest, the crater was widened to the north and ash clouds 
flowed outside the crater. A lava dome appeared close to the vent of subplinian events within the crater, growing at a high effusion rate. During the dome growth, vulcanian events occurred at the subplinian vent. Degassing occurred effectively without destruction of the growing dome. The lava dome grew, swelling and extending for four days, and covered the subplinian vent. When an intense vulcanian event occurred on 1 February, the lava dome was deflated, and the vulcanian stage started. The eruption ended with phreatomagmatic events during June-September.

The total amount of magma erupted in the 2011 eruption is $2.1-2.7 \times 10^{7} \mathrm{~m}^{3}$ DRE. The magma discharge to the surface had almost finished on 1 February and continued at the low rate in early February 2011. Although re-inflation suggested magma re-supply after February, it had stopped in the end of 2011. The 2011 eruption was much smaller in scale than the 1716-17 eruption. The sequences are also different; the latter includes repetition of larger subplinian events and draining-back of the lava accumulated in the crater.

Acknowledgments. We would like to Kazuo Shimousuki, Takeharu Nagatomo, Tetsuo Kobayashi, and Japan Meteorological Agency for providing us photographs used in this paper. Field survey was supported by Yasuo Miyabuchi, Tetsuo Kobayashi, Natsumi Hokanishi, and the General Observation Team organized under the National Coordination Committee for Volcanic Eruption Prediction. The software to view continuous seismic waves and video-images simultaneously, WAVE_VS_IMAGE, developed by Mie Ichihara was very effective in this study. This research was supported by MEXT KAKENHI Grant No. 22900001 (SN). We thank Chris Newhall and Hiroshi Shinohara for careful reading of our manuscript and for giving useful comments.

\section{References}

Cashman, K. V., Volatile controls on magma ascent and eruption, in The State of the Planet: Frontiers and Challenges in Geophysics, edited by R. S. J. Sparks and C. J. Hawkesworth, Geophysical Monograph, AGU, 109-124, 2004.

Cashman, K. V. and S. M. McConnell, Multiple levels of magma storage during the 1980 summer eruptions of Mount St. Helens, WA, Bull. Volcanol., 68, 57-75 doi:10.1007/s00445-005-0422-x, 2005.

Cioni, R., P. Marianelli, R. Santacroce, and A. Sbrana, Plinian and subplinian eruptions, in Encyclopedia of Volcanoes, edited by H. Sigurdsson, B. Houghton, S. R. McNutt, H. Rymer, and J. Stix, Academic Press, 477-494, 2000.

Endo, K. and T. Kobayashi, Quaternary (Daiyonki), Field Geology 9, Kyoritsu Shuppan, 201 pp., 2012 (in Japanese).

GIAJ (Geospatial Information Authority of Japan), Crustal deformations around Kirishima Volcano, Rep. Coord. Comm. Predict. Volcan. Erup., 107, 167-174, 2011 (in Japanese).

GIAJ (Geospatial Information Authority of Japan), Crustal deformations around Kirishima Volcano, Rep. Coord. Comm. Predict. Volcan. Erup., 108, 197-220, 2012 (in Japanese).

Geshi, N., S. Takarada, M. Tsutsui, T. Mori, and T. Kobayashi, Products of the August 22, 2008 eruption of Shinmoedake Volcano, Kirishima Volcanic Group, Japan, Bull. Volcanol. Soc. Jpn., 55, 53-64, 2010 (in Japanese with English abstract).

Ichihara, M., J. J. Lyons, and A. Yokoo, Switching from seismic to seismoacoustic harmonic tremor at a transition of eruptive activity during the Shinmoe-dake 2011 eruption, Earth Planets Space, 65, this issue, 633643, doi:10.5047/eps.2013.05.003, 2013.

Imura, R., Eruptive history of the Kirishima volcano during the past 22,000 years, Geograph. Rep. Tokyo Metropolitan Univ., 27, 71-89, 1992.

Imura, R. and T. Kobayashi, Eruptions of Shinmoedake Volcano, Kirishima Volcano Group, in the last 300 years, Bull. Volcanol. Soc. Jpn., 36, 135-148, 1991 (in Japanese with English abstract).

Ishihara, K. and S. Teraishi, Shinmoe-dake eruption in Kirishima Mountains, DPRI Newsletter, Disaster Prevention Research Institute, Kyoto,
University, No. 60, 6-7, 2011 (in Japanese).

JMA (Japan Meteorological Agency), National Catalogue of the Active Volcanoes in Japan (third edition), Japan Meteorological Agency, 635 p., 2005 (in Japanese).

JMA (Japan Meteorological Agency), Volcanic activity of Kirishimayama Volcano-June-September 2010-, Report of Coordinating Committee for Prediction of Volcanic Eruption, 107, 154-166, 2011 (in Japanese).

JMA (Japan Meteorological Agency), Voclanic activity of Kirishimayama Volcano-February 2011-May 2011-, Report of Coordinating Committee for Prediction of Volcanic Eruption, 109, 139-167, 2012 (in Japanese).

Kagiyama, T., H. Utada, M. Uyeshima, F. Masudani, W. Kanda, Y. Tanakada, H. Masuda, H. Murakami, I. Shiozaki, M. Ichiki, T. Yukutake, T. Mogi, K. Amita, N. Oshiman, and M. Mishina, Resistivity structure of the central and the southeastern part of Kirishima volcanoes, Bull. Volcanol. Soc. Jpn., 41, 215-225, 1996 (in Japanese with English explanation).

Kaneko, T., T. Ohminato, T. Koyama, M. Takeo, A. Watanabe, T. Shimano, T. Yanagisawa, Y. Aoki, A. Yasuda, and Y. Honda, The summit crater of Mt Shinmoe and the adjacent areas, taken from unmanned autonomous helicopter, Bull. Volcanol. Soc. Jpn., 56, 171-173, 2011 (in Japanese with English abstract).

Kato, K. and H. Yamasato, The 2011 eruptive activity of Shinmoedake volcano, Kirishimayama, Kyushu, Japan-Overview of activity and Volcanic Alert Level of the Japan Meteorological Agency-, Earth Planets Space, 65, this issue, 489-504, doi:10.5047/eps.2013.05.009, 2013.

Kozono, T., H. Ueda, T. Ozawa, T. Koyaguchi, E. Fujita, A. Tomiya, and Y. Suzuki, Magma discharge variations during the 2011 eruptions of Shinmoe-dake volcano, Japan, revealed by geodetic and satellite observations, Bull. Volcanol., 2013 (in press).

Maeno, F., M. Nagai, S. Nakada, R. Burden, S. Engwell, Y. Suzuki, and T. Kaneko, Constraints on tephra dispersal from andesitic subplinian explosions of the Shinmoedake volcano, Kirishima, Japan, on 26-27 January 2011, Bull. Volcanol., (in review).

Maeno, F., S. Nakada, M. Nagai, and T. Kozono, Ballistic ejecta and eruption condition of the vulcanian explosion of Shinmoedake volcano, Kyushu, Japan on 1 February, 2011, Earth Planets Space, 65, this issue, 609-621, doi:10.5047/eps.2013.03.004, 2013.

Miyabuchi, Y., D. Hanada, H. Niimi, and T. Kobayashi, Stratigraphy, grain-size and component characteristics of the 2011 Shinmoedake eruption deposits, Kirishima Volcano, Japan, J. Volcanol. Geotherm. Res., doi:10.1016/j.jvolgeores.2013.03.027, 2013.

Morrissey, M. M. and J. G. Mastin, Vulcanian eruptions, in Encyclopedia of Volcanoes, edited by H. Sigurdsson, B. F. Houghton, S. R. McNutt, H. Rymer, and J. Stix, Academic Press, 463-475, 2000.

Nagaoka, S. and M. Okuno, Tephrochronology and eruptive history of Kirishima volcano in southern Japan, Quat. Int., 246, 260-269, 2011.

Nakao, S., Y. Morita, H. Yakiwara, J. Oikawa, H. Ueda, H. Takahashi, Y. Ohta, T. Matsushima, and M. Iguchi, Volume change of the magma reservoir relating to the 2011 Kirishima Shinmoe-dake eruption-Charging, discharging and recharging process inferred from GPS measurements, Earth Planets Space, 65, this issue, 505-515, doi:10.5047/eps.2013.05.017, 2013.

NIED (National Research Institute for Earth Science and Disaster Prevention), Crustal deformation associated with the 2011 eruption of the Kirishima volcano (Shinmoe-dake), Rep. Coord. Comm. Predict. Volcan. Erup., 108, 221-226, 2012 (in Japanese).

Sasaki, H., K. Isobe, S. Homma, M. Sakagami, S. Mukoyama, S. Nakada, T. Kobayashi, and M. Murakami, Estimation of lava volume using oblique aerial photo in Shinmoedake Volcano, Abstract, 2011 Fall Meeting, Volcanological Society of Japan, A1-13, 2011 (in Japanese).

Shimbori, T. and K. Fukui, Time variation of the eruption cloud Echo height from Shinmoe-dake Volcano in 2011, observed by Tanegashima and Fukuoka weather radars, Rep. Coord. Comm. Predict. Volcan. Erup., 108, 189-196, 2012 (in Japanese).

Shimizu, O., T. Jitousono, E. Shimokawa, T. Yamakoshi, H. Kisa, S. Takiguchi, and M. Sugiyama, Properties of tephra-covered slopes and sediment movement after Januaruy-2011 eruption of Shinmoedake, Kirishima volcano, J. Jpn. Soc. Erosion Control Eng., 64, 46-56, 2011 (in Japanese).

Suzuki, Y., M. Nagai, F. Maeno, A. Yasuda, N. Hokanishi, T. Shimano, M. Ichihara, T. Kaneko, and S. Nakada, Precursory activity and evolution of the 2011 eruption of Shinmoe-dake in Kirishima volcanoinsights from ash samples, Earth Planets Space, 65, this issue, 591-607, doi:10.5047/eps.2013.02.004, 2013a.

Suzuki, Y., A. Yasuda, N. Hokanishi, T. Kaneko, S. Nakada, and T. 
Fujii, Syneruptive deep magma transfer and shallow magma remobilization during the 2011 eruption of Shimoe-dake, Japan-Constraints from melt inclusions and phase equilibria experiments-, J. Volcanol. Geotherm. Res., 257, 184-204, doi:10.1016/j.jvolgeores.2013.03.017, $2013 \mathrm{~b}$.

Tsutsui, M., K. Tomita, and T. Kobayashi, Fumarolic activity since December 2003 and volcanic activity during the Meiji and Taisho eras (1880 1923) of Ohachi Volcano, Kishirima Volcano Group, Southern Kyushu, Japan, Bull. Volcanol. Soc. Jpn., 50, 475-489, 2005 (in Japanese with English abstract).
Walker, G. P. L., Explosive volcanic eruption-a new classification scheme, Geol. Rund., 62, 431-446, 1973.

Wilson, L., R. S. J. Sparks, and G. P. L. Walker, Explosive volcanic eruptions. IV. The control of magma properties and conduit geometry on eruption column behaviour, Geophys. J. R. Astron. Soc., 63, 117-148, 1980.

S. Nakada (e-mail: nakada@eri.u-tokyo.ac.jp), M. Nagai, T. Kaneko, Y. Suzuki, and F. Maeno 